\title{
“Quem vai orar?!”: Os discursos religiosos entre adultos e crianças em uma escola pública de educação infantil
}

\author{
Jordanna Castelo Branco*
}

\begin{abstract}
Resumo
O presente trabalho tem como objetivo analisar os discursos religiosos que circulam entre adultos e crianças em uma escola de Educação Infantil da rede pública municipal da região metropolitana do Rio de Janeiro. Foi realizada uma pesquisa qualitativa, de inspiração etnográfica numa escola da rede pública municipal que contou com observação direta e entrevistas semi estruturadas com os professores e a direção da escola. O estudo apontou que a presença dos discursos religiosos presentes na escola Educação Infantil da rede pública municipal campo da pesquisa eram naturalizados por adultos e crianças, sendo excludentes e discriminatórios.

Palavras-chave: Escola pública, Educação Infantil, discurso religioso.
\end{abstract}

\section{“Who is going to pray?": Religious discourses among adults and children in an Early Childhood public school}

\begin{abstract}
This study aims to analyze the religious discourses that circulate among adults and children in a school of Early Childhood Education of the municipal public network of the metropolitan region of Rio de Janeiro. A qualitative survey was conducted of ethnographic inspiration in a municipal public school attended by direct observation and semi structured interviews with teachers and the direction. The study found that the presence of religious discourses present in kindergarten school municipal public field of research were naturalized by adults and children.
\end{abstract}

Keywords: Public school, Childhood, Religion discourse.

\section{Introdução}

De acordo com Fischmann (2008), a esfera pública é um espaço de todos. É na esfera pública que se busca garantir a democracia e a possibilidade da coexistência da diversidade. Dentre os seus aspectos está o respeito à crença e a não crença, sendo a neutralidade do espaço público fundamental para a convivência pacífica e democrática da pluralidade. A esfera pública numa sociedade democrática se caracteriza pela garantia da liberdade de consciência. Ela é expressa pelo direito de todos de "viverem sua singularidade como indivíduos e como coletividade sem motivos para se colocar em situação de subordinação a outro modo de crer ou convicção distinta da que se tem" (FISCHMANN, 2008, p.16). A esfera pública é o espaço regido pela lógica da cidadania, da liberdade e da justiça. Não envolve o divino, nem a crença no sobrenatural ou no intangível, uma lógica que varia de uma crença para outra. O espaço público é o lugar onde se busca que todos sejam vistos de maneira igualitária por serem considerados cidadãos, independente da sua crença ou não crença. Nele deve prevalecer a lógica da cidadania. Dessa forma, a presença da religião imposta por um ou mais grupos religiosos que extrapolam o limite de sua esfera privada para

\footnotetext{
*Endereço eletrônico: jordanna.branco@gmail.com
}

monopolizar ou tornar-se hegemônico - levará à exclusão dos demais, promovendo a descriminação.

Nessa direção um dos importantes espaços públicos é a escola pública. Esta compreendida como toda aquela financiada e mantida com recursos públicos que oferecem educação escolar, a Educação Básica, a todos os cidadãos. A escola pública como parte da esfera pública deve garantir a convivência pacífica e democrática da diversidade, regida pela lógica da cidadania. Onde todos os cidadãos devem ser tratados de maneira igual, independente da sua crença ou não crença. É esse entendimento que garante a escola pública enquanto o lugar da não discriminação religiosa.

A presença da religião nas escolas públicas brasileiras vem sendo ampliada por meio das conquistas sucessivas das instituições religiosas, sobretudo da Igreja Católica, nas legislações federais e infraconstitucionais para implantar o ensino religioso nesses espaços. Para Cunha (2011), o campo educacional tem sofrido interferências do campo religioso. Destaca a interferência de âmbito ideológico, que se dá por meio de legislações educacionais que implementam direta ou indiretamente o ensino religioso na rede pública educacional. Os estudos de Branco e Corsino (2006), Fischmann (2008), Grassi (2012) mostram que a 
presença da religião não se dá apenas por intermédio do Ensino Religioso. Tal presença pode ser observada também nas unidades de ensino que não oferecem a disciplina em sua grade curricular. Os autores mencionados em suas pesquisas revelam que nas escolas sem ensino religioso são expostos símbolos religiosos, como a cruz, a Bíblia e as imagens de santos. Além de serem realizadas orações, comemoração de festas religiosas, divulgação de eventos ligados a igrejas etc.

Diante disso, busco analisar os discursos religiosos que circulam entre adultos e crianças numa escola de Educação Infantil da rede pública municipal da região metropolitana do Rio de Janeiro. $\mathrm{O}$ artigo está organizado da seguinte maneira: pressupostos teóricos; contextualização do campo; análise dos discursos religiosos entre adultos e crianças e conclui com as reflexões sobre a presença dos discursos religiosos na escola pública municipal de Educação Infantil pesquisada.

\section{Pressupostos teórico-metodológicos da pesquisa}

Tomo como referencial teórico os estudos da linguagem de Mikhail Bakhtin, dentro do qual desataco o conceito de discurso. Para Bakhtin, os nossos discursos são repletos de palavras alheias (CORSINO, 2003). A maioria das informações e opiniões por nós enunciadas tem como referência as palavras do outro e ao transmitirmos as palavras alheias, formulamos o nosso discurso fazendo introduções, seleções e acentuações, ou seja, imprimimos nossas marcas às palavras alheias ao nos apropriar delas e as enunciarmos. Quem fala a palavra do outro tem seus interesses e intenções e usa procedimentos de transmissão variados, tanto no que concerne ao gênero quanto no que diz respeito ao enquadramento interpretativo. A articulação, a transmissão e a significação dos discursos alheios são produzidas de acordo com o contexto. Para o autor, os discursos se colocam no nível ideológico de formação do homem, com nítida intenção de definir atitudes e comportamentos, como é o caso de muitos discursos pedagógicos e religiosos (CORSINO, 2003, p.2). Uma das formas pelas quais os discursos podem surgir é a dogmática. Ela se coloca ao outro de forma engessada, monológica e sem possibilidade de réplica, interiorizada como dogma, destituindo o sujeito de autoria, o que leva ao agir tutelado por prescrições, sem efetivas transformações no sujeito. A partir disso entendo como discursos religiosos aqueles pautados em dogmas, sem a possibilidade de réplicas, engessados, monológicos.
Outro importante referencial são os estudos de Walter Benjamin. Eles trazem elementos para se compreender a infância como construção histórica, cultural e social e as crianças como sujeitos produtores de cultura que criam o seu mundo próprio dentro de um mundo maior. O conceito de infância entendido não como uma etapa cronológica que antecede à juventude e à maturidade, mas sim como um momento marcado por experiências (KRAMER, 1996). Estas, por sua vez, vão para além do viver algo, é o compartilhar pela narrativa de um fato vivido, cheio de sentidos e significados. É nas experiências que a criança significa e ressignifica o mundo a sua volta, se descobre e se constitui enquanto sujeito. A criança vê o mundo e o ressignifica continuamente. A criança está inserida na cultura e é produtora dela.

Com base no que foi dito acima no presente texto, busco conhecer e analisar os discursos religiosos - enunciados pelos adultos e destinados às crianças - que circulam em uma escola de educação infantil, campo desta pesquisa. A partir da perspectiva bakhtiniana, compreendo o campo como um auditório repleto das mais diversas vozes que, ao serem registradas, permitem análises e interpretações num processo dialógico com o próprio pesquisador. Para isso, tomo como base outro conceito bakhtianiano, o de exotopia. Este significa o desdobramento de olhares a partir de um lugar exterior (BAKHTIN, 2006, p.14). O movimento de desdobrar-se para chegar mais perto do objeto. A aproximação e o distanciamento são movimentos necessários ao pesquisador para se compreender os diferentes sujeitos envolvidos. O desdobramento de olhares nos leva a sair do nosso lugar e estranhar o familiar, tentar perceber aquilo que o outro não vê e simultaneamente, a maneira como ele percebe o lugar em que está inserido, mostrar o que vê o olhar do outro.

De acordo com André (1995), a estratégia etnográfica requer que o pesquisador realize observação participante, entrevistas e análise de documentos. A observação participante exige que o pesquisador não apenas observe, mas também participe como membro do grupo. A aproximação mais efetiva permite que o pesquisador busque captar a compreensão dos sentidos e da organização social da situação estudada a partir da perspectiva dos de dentro, aprendendo a se tornar um membro do grupo. As entrevistas têm a finalidade de aprofundar as questões e esclarecer os problemas observados. Os documentos ajudam "a contextualizar os fenômenos, explicitar as vinculações mais profundas e completar 
as informações coletadas através de outras fontes" (ANDRÉ, 1995, p.28).

Com intuito de conhecer os discursos religiosos que circulavam no cotidiano de uma escola pública municipal de Educação Infantil e apoiada nestes pressupostos teórico-metodológicos, foi realizada uma pesquisa qualitativa de inspiração etnográfica que contou com observações participantes e entrevistas semi-estruturadas com professores e com a direção da escola. As observações foram realizadas em uma turma de crianças de 5 e 6 anos de idade no turno da manhã, durante 8 meses, e contaram com registro em caderno de campo, em áudio e fotográfico.

\section{A religião nas escolas públicas: o município em questão}

O município no qual se situa a escola estudada não possui lei específica para a disciplina de ensino religioso. Segundo Fernandes (2012), baseia-se diretamente na legislação federal, lei n. ${ }^{\circ}$ 9475/97, e não na lei estadual 3459/2000, que implementou o ensino religioso confessional facultativo nas escolas da rede pública estadual do Rio de Janeiro. A autora em seus estudos constatou que, de acordo com o manual da Coordenação do ensino religioso do departamento ligado à Secretaria Municipal da Educação (SME) do município estudado, o ensino religioso fundamenta-se legalmente no Artigo $\mathrm{n}^{\mathrm{o}}$ 210, parágrafo $1^{\mathrm{o}}$, da Constituição Federal de 1988 e na lei no $9475 / 97$ que deu nova redação ao Artigo ${ }^{\circ} 33$ da Lei de Diretrizes e Bases da Educação Nacional (LDB) no 9.394/96. Além da legislação citada, há ainda dois instrumentos legais, que não constam do manual apresentado e não determinam as ações relativas ao ensino religioso implantado pela Coordenação dessa disciplina. Um deles é o decreto $n^{\circ} 4238 / 2003$, da Prefeitura Municipal, que instituiu o Sistema Municipal de Ensino do Município, determinando, no seu Artigo $n^{\circ} 25$, que o ensino religioso, de matrícula facultativa, constitui disciplina dos horários normais das escolas públicas de Ensino Fundamental, sendo oferecido, sem ônus para os cofres públicos, de acordo com as preferências manifestadas pelos alunos ou por seus responsáveis, em caráter: (i) confessional, de acordo com a opção religiosa do aluno ou de seu responsável, e ministrada por professoras ou orientadores religiosos preparados e credenciados pelas respectivas igrejas ou entidades religiosas; (ii) interconfessional, resultante de acordo entre as diversas entidades religiosas, que se responsabilizarão pela elaboração do respectivo programa.

Conforme dados da Secretaria Municipal de Educação (SME) do município investigado, em 2011, o ensino religioso era oferecido em 35 das 253 escolas da sua rede pública municipal de ensino e a disciplina contava com 38 professores. Fernandes (2012) afirma que o ensino religioso é ofertado na rede há aproximadamente 23 anos. Desde 2001, a proposta tem sido "enfatizar os valores humanos, o respeito ao diferente e às diferenças, voltando-se para a prática da solidariedade e do diálogo em consonância com os princípios democráticos", segundo a coordenação do ensino religioso do município (FERNANDES, 2012, p. 25).

A legislação educacional não estabelece o oferecimento do ensino religioso para as crianças pequenas, nem as escolas de Educação Infantil estão entre as selecionadas pela coordenação de ensino religioso para oferecimento da disciplina e envio de professores. No entanto, os espaços ocupados pela Secretaria de Educação Infantil no prédio da prefeitura eram repletos de imagens e dizeres de cunho religioso. Nessa mesma direção, as observações do campo da pesquisa revelaram a presença de práticas e ensinamentos de cunho religioso numa das escolas de Educação Infantil da rede pública municipal estudada.

\section{Contextualizando a escola}

A escola ${ }^{1}$ ficava localizada em frente a uma Comunidade às margens da principal via de acesso entre dois municípios. No seu entorno, havia três igrejas evangélicas, um terreiro, uma escola de Ensino Fundamental da rede pública municipal e um Centro Integrado de Educação Pública. Nos muros de entrada das duas instituições educacionais estavam escritas frases religiosas.

A escola pesquisada atendia a cerca de 130 crianças de 2 a 5 anos, organizadas em 6 turmas, uma de crianças de 2 anos e outra de crianças de 3 anos em tempo integral, e 4 turmas de tempo parcial, duas de crianças de 5 anos, no turno da manhã, e duas de crianças de 4 anos, no turno da tarde. Em cada turma havia cerca de 20 crianças, que contavam com uma professora e com, pelo menos, uma estimuladora ${ }^{2}$, sendo que as turmas com crianças de 2 e 3 anos tinham duas estimuladoras.

A religião transbordava dos corredores para o restante da escola. Nas paredes da secretaria, havia a letra de uma música evangélica acompanhada de desenhos de pássaros, plantas e crianças. Nas salas 
de atividades, havia livros de temáticas bíblicas nas estantes destinadas às crianças. Materiais da mesma temática marcavam presença na sala dos professores: DVD, livros, bíblias e pequenos dizeres com versículos bíblicos. Os corredores eram marcados por mensagens religiosas. $\mathrm{Na}$ entrada havia quadros com fotos da natureza em meio à citação de versículos bíblicos e à imagem de uma criança abraçada a um globo e outra com as mãos postas em posição de prece. Nem a cozinha da escola ficava de fora, pois, na geladeira, havia um enorme calendário do Smilinguido, personagem das estórias em quadrinhos evangélicas. A materialidade dos espaços revelava a presença de marcas do cristianismo em todos os espaços da escola pública municipal. Além disso, mostravam que as imagens, quadros e materiais de temáticas religiosas estavam destinados aos adultos. A altura dos quadros e imagens estavam fora do campo visual das criança e também ocupavam lugares de pouca circulação dos pequenos. Os livros, os DVD etc eram endereçados aos professores por ficarem no acervo da sala destinada a eles. Então, quais os discursos destinados às crianças?

A partir dessas constatações, foram realizadas observações em uma turma de 25 crianças de 5 e 6 anos de idade, do turno da manhã. A escolha da turma se deu com base na entrevista realizada no estudo exploratório. Nela, a professora da turma afirmou que a escola era laica. A rotina da turma foi acompanhada durante oito meses. A aproximação do campo foi gradual. Durante os 3 primeiros meses foram realizadas visitas semanais e nos dois últimos se tornaram diárias. As observações focalizaram: i) conhecer os discursos religiosos que circulam na escola destinados às crianças ; ii) conhecer e analisar as funções que estes discursos exercem nas interações entre adultos e crianças; iii) observar como as crianças significam o discurso religioso a elas endereçados.

\section{A comemoração do Dia das Crianças}

Para comemorar o Dia das Crianças, foi proposta uma programação especial. Em entrevista, a diretora destacou que dentre as atividades estava a apresentação de um "teatrinho" realizado pelo ministério infantil da sua igreja, sugerido por um grupo de professoras da escola. A apresentação foi realizada no pátio coberto. As professoras das turmas de 5 e 6 anos sentaram as crianças no chão do pátio em fileiras. $\mathrm{O}$ espaço era pequeno e as crianças ficavam muito próximas umas das outras.
O "teatro" foi encenado por duas religiosas. Uma estava caracterizada de criança, com prendedores de cabelo e roupas coloridas, e a outra de lavadeira, usava um lenço na cabeça e segurava um balde com algumas peças de roupa. O teatro consistia na alternância de falas e músicas de temática religiosa. No momento das falas, boa parte das crianças cochichavam ou tentavam se mexer ou olhavam desatentas. Já durante as músicas participavam empolgadas, cantavam aos gritos e dançavam.

O "teatrinho" era compreendido pelos adultos como espetáculo. Porém, conforme Desgranges (1998), o espetáculo teatral envolve dois eixos: a obra e o espectador. A obra teatral tem como ponto central a narrativa. E o espectador exerce o papel de contemplador, em um movimento que se aproxima da obra, vivenciando-a, e, em seguida, afasta-se dela e reflete sobre ela, compreendendo-a. O espectador dialoga com a obra ao partilhar sentimentos e emoções a partir do fato narrado. Já o "teatrinho" tratava-se de uma sequência de músicas costuradas por falas de conteúdo dogmático, desprovida de uma narrativa. Em alguns momentos, as falas pareciam desconexas, sem relação. Era distinto do que seria de fato uma apresentação teatral propriamente dita, como pode ser observado no diálogo a seguir:

Uma das atrizes, que interpretava a lavadeira, retirava com ar de suspense peças de roupa de um balde e perguntava para a platéia o que significava as suas cores:

- Biquíni amarelo para botar no peito!? Amarelo, representa? - pergunta a lavadeira com ar de surpresa, enquanto as crianças olhavam atentas. Em seguida caiam todos na gargalhada.

- O sol!- diz uma das crianças empolgada

- Representa o céu!- diz a lavadeira em tom de desapontamento.

- É azul!?- diz outra criança questionando. - O céu azul é amarelo... Deus criou ruas de ouro... E qual a cor do ouro?- pergunta a lavadeira tentando contornar a situação.

- Amarelo!- as crianças respondem numa só voz aos berros.

E a lavadeira continua retirando outra peça de roupa:

- Preto?! É uma sunga preta? E o preto?pergunta novamente a atriz com ar de brincadeira

- Luz apagada!- respondeu uma criança com 
naturalidade.

- Coisa que não entra no céu!- outra criança responde.

- Criança malcriada, pecado! Tudo que deixa o coração de Deus triste. Palavrão!diz a atriz com ar de tristeza e ironia.

(Diário de campo em 13/10/2010)

As vozes das crianças eram abafadas pelas dos adultos. Eles faziam perguntas para as crianças, mas desconsideravam as suas respostas. Traziam como definitivas respostas pautadas em preceitos religiosos. $\mathrm{O}$ evento revela a incongruência entre o mundo adulto e o infantil. Emergiram interpretações das crianças a respeito das palavras dos adultos, contrárias às por eles esperadas, imbuídos de difundir sua profissão de fé. Neste evento as crianças foram silenciadas.

Os adultos envolvidos no "teatrinho" pareciam acreditar que todas as crianças compartilhavam da religião deles, inclusive de seus símbolos religiosos. As perguntas direcionadas às crianças, com respostas pré-determinadas, pareciam buscar eco nas vozes infantis, o que não acontecia. Os adultos usavam como referência os símbolos religiosos do cristianismo, mais especificamente os difundidos entre os evangélicos. Isso fica claro ao associar o céu ao ouro, uma vez que dentro das histórias bíblicas contadas nas igrejas evangélicas, no céu as ruas são de ouro. As crianças diante da apresentação buscavam referências em suas experiências infantis, muito ligadas ao seu cotidiano, quando questionadas a respeito da simbologia utilizada. A total desarmonia entre perguntas e respostas pareciam não incomodar muito aos adultos envolvidos, pois o que estava em questão era a difusão de uma simbologia religiosa.

Após trechos de fala as personagens cantavam e dançavam. As músicas apresentadas no desenrolar do "teatrinho" tinham o ritmo rápido e eram acompanhadas por gestos, cada música tinha a sua coreografia. As crianças eram convidadas a cantar e dançar junto com as atrizes. As músicas complementavam as falas ou procuravam dar fluidez ao texto, costurar uma fala a outra. A letra das músicas também girava em torno de preceitos e dogmas religiosos, como mostra o episódio baixo:

A atriz que interpretava a lavadeira mostra para a atriz vestida de criança:

-Sou um soldado. Tenho uma espada e ela não machuca ninguém - A lavadeira mostra a biblia.
-É uma bíblia!!!- responde a outra atriz. -Na bíblia tem todas as coisas. A biblia é a arma do soldado. A gente fica mais forte! Quem quer ser soldado de Cristo?-pergunta a lavadeira.

- Eu!!!!!- respondem, aos berros, as crianças animadas.

A atriz vestida de criança convida as crianças a cantarem e marcharem junto com ela:

Mesmo que eu não marche na cavalaria, nem na infantaria, nem na artilharia, nem aviador seja eu

Soldado de Cristo eu sou! (2x)"

(Diário de campo 13/10/2010)

A intenção das atrizes era propagar os dogmas através das músicas. O ritmo agitado das músicas, as coreografias e a oferta de vivenciar um personagem envolvia as crianças. Os argumentos de convencimento junto aos futuros soldados estavam embasados no ideário do fantástico, de entrar no mundo do faz de conta. Os indícios estavam em dizer que a "arma não machuca ninguém" e "vai ficar forte". Nessa perspectiva, as crianças poderiam ser o que desejassem e nada mais convidativo do que ser um soldado, para crianças entre 5 e 6 anos. A oferta da possibilidade de ser um soldado com direito à espada e a marchar pelo pátio entreteve as crianças, que uma a uma se levantavam com a postura rígida de soldado. A aceitação das crianças em vivenciar fazer parte de um exército era lida pelas atrizes como a indicação do desejo de alistamento em outro, o de evangélicos. Outro ponto interessante, foi a menção da bíblia como arma poderosa, tido como um dado fundamental, já que a bíblia é o livro norteador da fé cristã, sobretudo dos evangélicos. As crianças aceitarem se levantar, cantar a música e fazer a coreografia era visto pelas atrizes como mais do que participar e responder positivamente à proposta delas, significava que a pregação foi realizada com sucesso. A estratégia parecia convencer as crianças a fazerem parte do exército de Cristo.

As crianças ao ouvirem o convite aceitaram sem pestanejar. Iniciaram prontamente a dramatização de exército, cada uma delas incorporava a personagem de soldado. Sentados batiam com os pés no chão, cantavam as músicas aos berros. Alguns tentavam ficar de pé, mas a pedido dos adultos sentavam novamente. Tudo indicava que tratava-se da oportunidade para transgredir. Nesse caso, a transgressão significava a possibilidade de se mexerem, se olharem e até mesmo tocar uns nos 
outros durante a apresentação. Encarnar o personagem proposto era aproveitar de maneira intensa aquele precioso momento. Ser um soldado naqueles minutos era unir o desejo de movimentar-se com o faz de conta, era ser um soldado para poder bater os pés no chão, falar bem alto etc. Era uma grande brincadeira de faz de conta. Significava representar um personagem do mundo imaginário, vivenciar um soldado como nas histórias dos contos infantis. Qual criança que não queria ser um soldado com espada? Alistar-se no exército divino para cada criança era o momento, através do papel de soldado, para movimentar-se, levantar, marchar, rir, ao contrário dos adultos, que permaneciam enxergar nelas não só um grupo de novos adeptos à religião, como também um exército de Cristo, para conquistar outros para o reino celestial, suas famílias.

\section{“Quem vai orar?!”: as orações na rotina escolar}

Durante a estada no campo foi observada a realização de orações pelas professoras junto às crianças. As orações eram conduzidas pelas professoras regentes de turma. Em sua maioria tinham como temática principal agradecer a Deus. Os motivos para agradecimento variavam de acordo com o momento da rotina, algumas vezes estavam relacionados a acontecimentos inesperados. Para Bakhtin (2006), a modelagem dos enunciados ocorre na presença de formas relativamente estáveis da comunicação humana na vida cotidiana e é fixada pelos modos de vida e circunstâncias. Assim, o gênero oração, que dispõe de um repertório específico, tinha seus enunciados organizados de acordo com as circunstâncias e com os objetivos evidenciados pela professora.

A professora da turma observada iniciava as atividades do dia com orações de agradecimento a Deus. Foi relatado por ela, em conversa informal, que as orações eram realizadas antes de dar início às atividades por uma das crianças, escolhida por ela. $\mathrm{O}$ critério era o bom comportamento: a mais comportada orava. Afirmou que a oração fazia parte da rotina da turma. Independentemente do motivo, era realizada a prece de agradecimento a Deus, seja pelo dia que se iniciava ou pela superação de algo que ocorria fora da rotina, como pode ser visto a seguir.

A professora ao chegar em sala deixa as coisas em cima da mesa. Em seguida, cumprimenta a turma. Durante a sua fala foi interrompida pela secretária da escola, que pede para que ela mude o carro de lugar. A professora sai para estacionar novamente $o$ carro e ao retornar, diz:

- Hoje nós vamos agradecer a Deus, porque tivemos um imprevisto ${ }^{3}$.- completa aliviada - Mas, deu tudo certo. Quem vai orar? Antes que houvesse resposta, ela sugere: João ${ }^{4}$ ?! - $O$ menino fica em silêncio. $A$ professora inicia a oração:

- Senhor, Deus! - fala com a intenção de a turma repetir: - Quem quiser pode repetir. $o$ silêncio continua. A professora tenta novamente que as crianças a acompanhemVocês quererem agradecer pelo quê? algumas crianças conversam aos sussurros. A professora ouve e diz em tom de repreensão - Paulo?! Pedro?! Silêncio! - A professora de outra turma interrompe. As duas professoras começam a conversar e a oração é deixada para outro momento.

(Diário de campo 15/06/2011)

$\mathrm{O}$ fragmento traz à tona $\mathrm{o}$ discurso autoritário e monológico endereçado às crianças. A professora se referia a um imprevisto que havia acontecido com ela. Compartilha com as crianças o ocorrido com a entonação de um grande problema para todos: professora e crianças. A temática e o motivo da oração destituíam as crianças de autoria, pois para elas parecia não haver motivo para agradecer. A professora buscava que as crianças repetissem a oração por ela proferida, de maneira individual ou coletiva. $\mathrm{O}$ tom enunciativo e a rapidez com a qual a professora proferia a questão não permitiam que as crianças a respondessem. Tomava para si a palavra e, ao mesmo tempo em que parecia abrir espaço para a réplica das crianças, a professora as silenciava, o que é próprio do discurso autoritário. A tutela e o silenciamento das vozes infantis evidenciaram a imposição de uma prática religiosa e aceitação do discurso adulto. A contra palavra das crianças se traduziu no silêncio, na recusa por repetir a oração e no burburinho. Nos não ditos e subentendidos, estava o discurso das crianças. Mostravam não compartilhar da oração, nem do motivo pela qual era agradecido. Parecia não ter sentido algum, não ser uma demanda delas. Por outro lado, tinham a compreensão de que o discurso da professora não requeria uma resposta ativa e sim uma resposta passiva de quem se submete à posição hierárquica de dominado. As vozes caladas das crianças revelam a condição de quem está no lugar de submissão e contestação de ser colocada nessa 
posição, uma vez que não respondem da maneira esperada pela professora.

Também fazia parte da rotina a oração de agradecimento pelas refeições que era conduzida pela professora antes de comer. A oração era uma espécie de música, com alguns versos cantados e outros recitados, acompanhada por gestos. Esta também costumava ser proferida pela professora e repetida pelas crianças:

As crianças oram conduzidas pela professora da turma antes da refeição:

Bater palmas!

Esticar um braço para o lado, o outro para outro.

Cinco dedinhos nesta mão, cinco dedinhos na outra.

Vou juntar as minhas mãos para fazer a oração.

Papai do Céu, muito obrigado pela comidinha. Ora sagrada!

(Diário de campo 25/10/2010)

As acentuações dadas pela professora ao musicar a oração permitiam um entrelaçamento ou hibridização entre o gênero oração e o gênero cantiga infantil. Uma estratégia bastante usada pelos adultos para direcionar o comportamento das crianças. Ao considerar que todo enunciado é um elo da comunicação discursiva (BAKHTIN, 2006, p.289), entende-se que o falante, ao exercer sua posição ativa dentro de uma esfera, procura optar por gêneros discursivos que deem visibilidade às suas ideias e que permitam dar maior relevância a dados objetos e sentidos. A prece antes das refeições buscava mais do que agradecer, mas trazia também a disciplinarização e subordinação das crianças aos preceitos religiosos. A refeição era mais um momento em que a professora podia ensinar religião e doutrinar as crianças. De forma que, o direito à refeição paga pelo governo, tornava-se uma bênção ou dádiva divina.

A professora cantava em um tom de voz calmo e com boa dicção, para a compreensão de todas as palavras pelas crianças. Ficava clara a intenção de fixação pelas crianças, uma vez que também era cantada todos os dias antes das refeições de maneira a todas as palavras serem facilmente compreendidas. Pode-se afirmar que a entonação enunciativa ressaltava a intenção de doutrinar a turma. A oração em forma de música, assim como a anterior não permitia respostas, a intenção era apenas a sua repetição mesmo que de maneira menos dura e rígida. A tentativa de dar leveza dava a falsa sensação de ludicidade, de ser agradável às crianças. Elas cantavam empolgadas por parecer ser uma grande brincadeira, esticavam os braços, os dedos. Era uma espécie de relaxamento que antecedia às refeições. Ao mesmo tempo em que por ser uma oração cotidiana era realizada de maneira automática. No auditório social da instituição, crianças, seus responsáveis e professores encaravam com naturalidade as orações, como parte das práticas escolares.

\section{Não faz isso, Deus não gosta!: as reprimendas de cunho religioso}

As observações do campo, também, evidenciaram o discurso do bom comportamento que circulava interpenetrado pelo religioso. Este amálgama discursivo costumava ser enunciado com a finalidade de disciplinarização e docilização dos corpos. A professora repreendia as crianças diante de situações em que falavam, levantavam-se sem ser solicitadas ou mexiam-se durante as explicações, quer fosse para se coçar ou cutucar o colega, enfim eram exigidos das crianças o silêncio e a quietude dos corpos.

Para Foucault (1987), a disciplina e o controle minucioso das operações do corpo com uma determinada utilidade visam uma relação que torna o sujeito, ao mesmo tempo, obediente e útil. Trata-se do domínio do corpo do outro para ações como se quer que ele realize e com as tecnologias próprias para a fabricação de corpos submissos, corpos dóceis. O autor demonstra, em Vigiar e Punir, que um dos espaços em que a disciplina ocupa um lugar privilegiado é a escola. No caso desta instituição estudada, dentre os instrumentos disciplinares usados estava o da vigilância divina, em que Deus estava atento a todos os detalhes do comportamento e do pensamento daquelas crianças que ali estavam.

Imbuída desse espírito, de usar a religião como artifício disciplinar, a professora repreendia as crianças em diferentes situações, conforme mostra o episódio a seguir.

Na hora do almoço a professora leva as crianças para o refeitório. Enquanto a turma espera pela comida duas crianças se disputam o mesmo lugar a mesa. Na disputa uma empurra a outra para ver quem vai sentar primeiro. Em meio a empurrões e xingamentos a professora diz com firmeza: - Para! Não faz isso! Deus não gosta! As crianças se entreolham e voltam a cabeça 
para professora. Param de empurrar uma a outra, mas entreolham-se como se a disputa continuasse.

(Diário de campo 10/06/2011)

De acordo com a perspectiva bakhtiana, as enunciações são produzidas a partir das intencionalidades e do contexto enunciativo. A partir da articulação de tal perspectiva que se soma às ideias de Foucault, pode-se dizer que a professora se apropriava dos conteúdos e das entonações típicas da pregação das religiões evangélicas para repreender as crianças, retomar o controle e manter o bom comportamento. Esta implicava em não proferir palavras tidas como de baixo calão como também na ausência do toque no corpo do outro e movimentos inesperados, sendo inaceitável a ideia de agressão física, mesmo um leve esbarrão. Por fim, pode-se constatar que os enunciados eram organizados e determinados como um dispositivo de poder e controle no intuito de disciplinar os corpos e as mentes daqueles alunos.

Portinari pintava igrejas, céu e anjos Durante a leitura da biografia de Portinari para as crianças a professora dava ênfase nas palavras ligadas à religião.

- Portinari pintava igrejas.- a professora enfatiza a última palavra e as seguintes: - $O$ céu, os anjos.

- Papai do Céu - diz uma das crianças tentando participar, já que nos trechos anteriores foi solicitada a participação da turma.

(Diário de Campo 15/08/2011)

Nos enunciados descritos acima, as entonações davam ênfase às palavras: igreja, céu e anjos. A entonação evidenciou valores ideológicos da professora durante a enunciação do gênero biografia. A ênfase dada trazia uma valorização da igreja- local pintado por Portinari- e da temática por ele pintada. $\mathrm{O}$ valor se deslocava da biografia para o tema religioso. Quando a criança fala Papai do Céu continua no fluxo de comunicação enunciado pela professora.

Foi observado que a professora mencionava na frente da turma as suas expectativas e preferências pelas crianças cristãs, especialmente, as evangélicas. Outro ponto foram os elogios e a atenção dada às crianças que faziam menção a Deus e à participação em igrejas. Para entrar no jogo, mencionavam-se as palavras de valor ideológico no campo estudado. As crianças modelavam seus enunciados em sintonia com o que era pedido pelas circunstâncias.

As observações do campo, também, revelaram que os discursos religiosos nas atividades escolares iam para além das falas da professora. As professoras das turmas de 5 e 6 anos costumavam exibir para as crianças filmes ${ }^{5}$, dentre eles, os de temática religiosa. Eram exibidas histórias de personagens bíblicos, como Daniel na cova dos leões, ou de fundo religioso, com personagens cristãos que costumam orar, ir à igreja, como foi o caso de Os Vegetais. Ambos os tipos de filmes tratavam-se de produções voltadas para o público infantil e estavam, de alguma maneira, ligados à temática pedagógica trabalhada com as crianças, tal como, a exibição do filme Príncipe do Egito na Páscoa. Tinha a intenção de trabalhar a data comemorativa junto com as crianças e ensinar a sua história, origem. Os discursos religiosos também estavam inscritos no espaço escolar através dos materiais postos à disposição das crianças. Dentre os livros do cantinho da leitura, havia os de temática bíblica, como a coleção de personagens da bíblia, em que se incluíam histórias como as de Jesus, José e Daniel.

O mesmo aconteceu na festividade de encerramento do primeiro semestre. A intenção da direção, professores e estimuladoras era realizar uma grande festa literária para as crianças e suas famílias. A programação contava com contadores de histórias, atividades de pinturas de rosto, brincadeiras com histórias cantadas, teatro encenado pelas professoras. Dentre os espaços organizados para a realização da programação estava o cantinho da leitura. Nele foram colocados à disposição das crianças livros diversos, dentre os quais se destacavam pela quantidade e variedade os de temática bíblica. Havia histórias dos mais diversos personagens bíblicos publicados por diferentes editoras. Eram livros adequados a diferentes faixas etárias, de acordo com as atendidas pela escola. Tinham de livros variados, de livros pequenos e de papel plastificado e duro próprios para crianças de até 2 anos, a livros em papel mais barato e de qualidade inferior. Além disso, foi realizada, no final da festividade, uma oração com todos os presentes.

\section{Considerações Finais}

Assim, pode-se constatar que a presença da religião na escola pública materializada através dos discursos religiosos abre espaço para a discriminação. Ela vai na contra mão do que se 
espera do espaço público no Estado Democrático de Direito, o qual tem como princípio promover a cidadania e a igualdade entre os diferentes cidadãos. A presença dos discursos religiosos na escola pública evidencia a diferença, sobretudo entre aqueles que não compartilham do discurso hegemônico e os que compartilham dele. Os discursos religiosos hegemônicos são proferidos por aqueles estão numa posição de poder. $\mathrm{Na}$ escola campo da pesquisa, notou-se que os discursos religiosos eram proferidos por um grupo de professores apoiados pela diretora da mesma religião, no caso a evangélica, que eram dotados, neste espaço, da posição de poder.

Os discursos religiosos presentes na instituição de Educação Infantil estudada, enunciados pelos adultos no dia a dia, eram endereçados às crianças. Eles tinham a intencionalidade de doutriná-las. As professoras buscavam compartilhar a sua fé com as crianças, o que pode ser visto em vários momentos da rotina escolar. Elas se ocupavam em ensinar os dogmas de sua religião e as regras de comportamento de acordo com as mesmas. Buscam com que as crianças ajam da maneira por elas esperadas em consonância com a sua visão de mundo a partir da ótica da fé por elas professada. Isto pode ser visto no "teatrinho" encenado para as crianças, ao trazer enunciados que relacionavam as cores a preceitos da esfera cristã. As professoras estabeleciam junto as crianças uma relação em que utilizavam de discursos religiosos para modelar o comportamento visando, em especial, a quietude dos corpos: quanto menos as crianças se mexessem em sala melhor. Então, era enunciado intencionalmente discursos de caráter monológico e dogmático. Mesmo diante da não possibilidade de réplica, as crianças subvertiam a ordem. Era nos não ditos e subentendidos que iam pouco a pouco infringindo as regras dos adultos tecidas por via da religião. Ficava claro que os discursos enunciados em tom de verdades absolutas eram compreendidos majoritariamente de maneira subjetiva, ligados ao mundo imaginário. Viam muitas das propostas de cunho religioso como uma grande brincadeira, por exemplo, no teatrinho e nas orações cantadas. Muitas das imposições marcadas pelos adultos excluíam as crianças da possibilidade de compartilhar não só as suas opniões como também enunciar as suas religiões. Não havia outra alternativa senão a de ser adepto das religiões evangélicas e participar de modo efetivo das atividades de cunho religioso promovida sno espaço escolar pelas professoras e apoiadas pela diretora. Se todos tinham de proferir os mesmos discursos de uma única fé, haveria lugar para a diferença? A resposta é não. As crianças eram tolhidas da oportunidade de conviver com a diferença e se relacionar com ela. Estava aberto o caminho para a discriminação e a exclusão.

Assim, pode-se dizer que os discursos religiosos que circulavam em uma escola de Educação Infantil da rede pública municipal de uma metrópole brasileira eram vistos de maneira naturalizada por crianças e adultos. Os episódios descritos evidenciam que os discursos religiosos faziam parte do cotidiano da escola. Exerciam a função de organização das turmas para as atividades escolares em alguns momentos, como as reprimendas e a oração do almoço, e em outros da transmissão de ensinamentos de conteúdos religiosos, chegam a se confundir com o currículo da escola, por exemplo: as datas comemorativas. Em ambos os casos, os discursos religiosos silenciavam as crianças e desconsideravam aquelas que não compartilhavam da mesma fé na qual estavam imersos.

\section{Notas}

1 A escolha pela instituição estudada se deu através do critério da familiaridade, por ser a mesma o local de atuação profissional de uma colega do programa de pós-graduação. Isto permitiu a entrada no campo. Porém, em experiências anteriores, não foi possível a entrada no campo pelo posicionamento dos agentes educacionais, que afirmavam não haver ensino religioso nas escolas, logo, nem a presença da religião.

2 Eram consideras estimuladoras as profissionais que auxiliavam as professoras na execução das atividades e organização das turmas.

3 Era considerado imprevisto os acontecimentos que atrasassem o início da aula, como, por exemplo, a necessidade de mudar o carro de lugar por estar estacionado em lugar indevido .

4 Por motivos éticos, todos os nomes usados são fictícios.

5 Vale lembrar que os filmes e os livros religiosos não serão aqui analisados.

\section{Referências}

ANDRÉ, M. E. D. Etnografia da prática escolar. Campinas, SP: Papirus, 1995. 
BAKHTIN, M. Estética da Criação Verbal. São Paulo: Martins Fontes, 2006.

. Marxismo e Filosofia da Linguagem. São Paulo: HUCITEC, 1995.

BENJAMIN, W. Obras Escolhidas II: rua de mão única. São Paulo: Brasiliense, 1993.

BRANCO, J. C.; CORSINO, P. O ensino religioso em duas escolas de Educação Infantil em duas escolas no município do Rio de Janeiro: o que as praticar revelam?. Revisita Contemporânea de Educação, Rio de Janeiro: UFRJ, v.1, n.2, set-dez, 2006.

BRASIL. Constituição Federal de 1988. Acesso em janeiro de 2010. Disponível em:

http://www.planalto.gov.br/CCIVIL_03/Constituica o/Constitui\%C3\%A7ao.htm

BRASIL. Lei de Diretrizes e Bases da Educação Nacional. Acesso em junho de 2012. Disponível em:http://portal.mec.gov.br/seed/arquivos/pdf/tvesc ola/leis/lein9394.pdf

BRASIL. Lei n.9.475/97. Acessada em junho de $2012 . \quad$ Disponível em: http://www.planalto.gov.br/ccivil_03/leis/L9475.ht $\mathrm{m}$

CORSARO, W. Reprodução interpretativa e cultura de pares. In: MULLER, Fernanda e CARVALHO, Ana Maria Almeida (orgs). Teoria e prática na pesquisa com crianças: diálogos com William Corsaro. São Paulo: Cortez, 2009.

CORSINO, P. Infância, linguagem e letramento: Educação Infantil na rede municipal do Rio de Janeiro. Tese de Doutorado. Rio de Janeiro: Departamento de Educação, PUC-Rio, 2003.

CUNHA, L. A. Contribuição para a análise das interferências mercadológicas nos currículos escolares. Revista Brasileira de Educação, Rio de Janeiro, v.16, n. 48, set-dez, 2011.

DESGRANGES, F. Teatro do sem sujeito manda lembranças: um pequeno estudo sobre o espectador do teatro éprico. In: KRÂMER, Sônia e LEITE, Maria Isabel (org). Infância e produção cultural. Campinas, São Paulo: Papirus, 1998.

DUQUE DE CAXIAS. Lei Orgânica do Município de Duque de Caxias. Acesso em agosto de 2012. Disponível em: http://www.leismunicipais.com.br/cgilocal/orglaw.pl ?city $=$ Duque $\% 20 \mathrm{de} \% 20$ Caxias\&state $=$ rj

FERNANDES, V. C. A religião nas escolas do município de Caxias: as diferentes formas de ocupação do espaço público. Notandum, v.28, jan./abr. 2012.

FISCHMANN, R. Estado Laico. São Paulo: Memorial da América Latina, 2008.

FOUCAULT, M. Corpos Dóceis. In: FOUCAULT, Michael.Vigiar e punir: nascimento da prisão. Petrópolis: Vozes, 1987.

GRASSI, L. G. I. O ensino religioso nas escolas municipais de ensino fundamental no município de São José dos Campos. In: Ensino religioso em escolas públicas: ameaças ao Estado Laico. FISCHMANN, Roseli. São Paulo: Porto, 2012.

KRAMER, S. Pesquisando infância e educação: um encontro com Walter Benjamin. In: KRAMER, Sônia e LEITE, Maria Isabel (orgs). Infância: fios $e$ desafios da pesquisa. Campinas, SP: Papirus, 1996.

RIO DE JANEIRO. Lei Estadual $\mathrm{n}^{\circ} 3459$. Acesso em março de 2013. Disponível em: http://alerjln1.alerj.rj.gov.br/CONTLEI.NSF/b24a2d a5a077847c032564f4005d4bf2/16b2986622cc9dff0 325695f00652111?OpenDocument.

\section{Sobre a autora}

Jordanna Castelo Branco: Pedagoga, Mestre e Doutoranda em Educação pela Faculdade de Educação da Universidade Federal do Rio de Janeiro (UFRJ). Também, é especialista em Educação Infantil pela Pontifícia Universidade Católica do Rio de Janeiro (PUC-Rio).

Recebido em setembro de 2015.

Aprovado em maio de 2016. 